\title{
CHEMOTAXONOMIC STUDY ON THYMUS XTOLETANUS LADERO AND ITS PARENTAL SPECIES
}

\author{
José Blanco SALAS ${ }^{1}$, MARÍA JosÉ PÉREZ-AlONSO², \\ TRINIDAd RUIZ TÉLlEZ ${ }^{3}$, FRANCISCO MARÍA VÁZQUEZ PARDO ${ }^{1}$ \\ ${ }^{1}$ Grupo HABITAT, \\ Departamento de Producción Forestal, Centro de Investigación Finca La Orden - Valdesequera. \\ Vicepresidencia Segunda y Consejería de Economía, Comercio e Innovación. \\ Junta de Extremadura. \\ Km. 372. 06187 Guadajira (Badajoz), Spain \\ e-mail: pepebsalas@yahoo.es \\ ${ }^{2}$ Universidad Complutense, \\ Facultad de Biología. Departamento de Biología Vegetal, Botánica \\ 28040. Madrid, Spain \\ ${ }^{3}$ Grupo de Investigación en Biología de la Conservación, \\ Área de Botánica, Facultad de Ciencias, Universidad de Extremadura \\ 06071. Badajoz, Spain
}

(Received: November 10, 2009. Accepted: February 23, 2010)

\begin{abstract}
We analysed the essential oils of cultivated material of Thymus xtoletanus Ladero and its parents, Th. mastichi$n a$ (L.) L. and Th. villosus subsp. lusitanicus (Boiss.) Coutinho, with seeds from the same locality in the centre of the Iberian Peninsula. The essential oil of Th. xtoletanus, which had not been analyzed previously, presented 1,8-cineole as the major component $(25.5 \%)$, as was also the case for Th. mastichina $(76.1 \%)$. Other components with a major presence in Th. xtoletanus and Th. villosus subsp. lusitanicus were [(Z)- $\beta$-ocimene (8.1\%); camphor (4.5\%); sabinene $(3.2 \%)$; $\alpha$-pinene $(2.8 \%)]$, and $[(Z)-\beta$-ocimene $(4.1 \%)$, camphor $(9.8 \%)$, sabinene $(2.8 \%), \alpha$ -pinene $(7.1 \%)$, respectively. However, in the hybrid the components $\beta$-phelandrene $(14.5 \%)$, limonene $(6.9 \%)$, $(E)$ - $\gamma$-bisabolene $(3.5 \%)$, and viridiflorol $(3.3 \%)$ stood out, inter alia, whereas their presence in the parents was limited. The study confirms the hybrid origin of Th. xtoletanus as intermediate between Th. mastichina and Th. villosus subsp. lusitanicus.
\end{abstract}

KEY WORDS: Thymus xtoletanus, Thymus mastichina, Thymus villosus subsp. lusitanicus, hybrid, chemotaxonomy, cultivation.

\section{INTRODUCTION}

Thymus xtoletanus Ladero is an endemism to the Iberian Peninsula. It was described from the Villuercas highlands (Cáceres, Spain) (Ladero 1970). It is a procumbent shrub of 10-50 cm, growing on acid soils whose structural support are quartzites, shales or sands, commonly associated with areas that have problems of erosion. The species appears at 1000-1400 m altitude as a constituent of the heather and cistus scrub which is the substitution stage of deciduous oak forest, and may also appear in the understorey of evergreen Quercus rotundifolia Lam. woodland. Its natural populations are currently in a phase of expansion (Blanco et al. 2007). They arise in the vicinity of populations of Th. mastichina (L.) L. and Th. villosus subsp. lusi- tanicus (Boiss.) Coutinho. Its morphology is intermediate between both of them. This fact has to be interpreted as evidence of its being a hybrid. Indeed, hybridization is common among thymes. In the Iberian Peninsula alone, more than 60 hybrids between taxa of this genus have been described (Morales 1995; Sanchez et al. 2004).

A notable character that Th. xtoletanus shares with $T h$. mastichina is the morphology of the mature leaves. With Th. villosus subsp. lusitanicus, it shares the form of the flower bracts and the form and arrangement of the teeth of the calyx. Other characters, such as the presence of cilia on the leaves, vary considerably from one population to another of Th. xtoletanus, so much so that three different nothomorphs have even been considered for the species (Ladero 1970). 
Chemotaxonomy has proven to be an effective tool to confirm or reject a taxon's hybrid nature by comparison with its putative parents (Tzakou and Constantinidis 2005). In the case of thymes, there have been antecedents of this type of analysis in Th. xenicensis Blanca (Sáez 1995), Th. xmonrealensis Pau ex R. Morales nothosubsp. garcia-vallejoi Sánchez-Gómez Alcaraz \& Sáez (Sáez 1995), Th. xarandanus Willk. (Soriano 1997), Th. xviciosoi Pau x Morales (Salgueiro et al. 1993), and Th. xmourae Paiva \& Salgueiro (Salgueiro et al. 2000a).

Herewith we report the first chemotaxonomic study of Thymus xtoletanus, and of Th. mastichina and Th. villosus subsp. lusitanicus as its putative parents. The aim is to determine the hybrid nature of the taxon based on knowledge of its chemical composition.

\section{MATERIAL AND METHODS}

\section{Plant material}

Seeds of Th. mastichina and Th. villosus subsp. lusitanicus were collected in the municipality of Alía, in the county of Las Villuercas, Cáceres province, Spain (30SUJ16). The seeds were subjected to a germination test following the ISTA (1999) protocol. Seedlings that emerged in the test were used to produce an experimental crop in the research centre Centro de Investigación La Orden-Valdesequera in Guadajira municipality, Badajoz province, Spain (29SPD90).

One of the individuals produced in the culture of Th. villosus subsp. lusitanicus was found to be Th. xtoletanus. When this individual reached some $25 \mathrm{~cm}$ in height and 30 $\mathrm{cm}$ diameter cover, it was multiplied vegetatively to obtain an experimental crop.

The crops of Th. mastichina, Th. villosus subsp. lusitanicus, and Th. xtoletanus were harvested in the flowering stage (2007-06-01). They were dried in an airy room in darkness, and then conserved for one month in paper bags. Vouchers were deposited in the Herbarium of the Centro de Investigación La Orden-Valdesequera, Junta de Extremadura (Th. mastichina HSS 41860; Th. villosus subsp. lusitanicus HSS 15418; Th. xtoletanus HSS 15419).

\section{Isolation of volatile components}

The extraction of the essential oils was carried out by means of hydrodistillation according to the method proposed by the European Pharmacopoeia (Council of Europe 1996). The essential oil sample obtained was used to estimate the essential oil yield $(\mathrm{mL} / 100 \mathrm{~g})$ and to determine its percentage composition.

\section{Gas chomatography}

The analytical GC was carried out on a Varian 3300 gas chromatograph fitted with a fused methyl silicone DB-1 column $(50 \mathrm{~m} \times 0.25 \mathrm{~mm}, 0.25 \mu \mathrm{m}$ film thickness). Temperature was programmed from $95^{\circ} \mathrm{C}$ to $240^{\circ} \mathrm{C}$ at $4^{\circ} \mathrm{C} \mathrm{min}-1$. Injection was performed at $250^{\circ} \mathrm{C}$ in the split mode $(1: 100)$. Nitrogen was used as the carrier gas $\left(1.5 \mathrm{~mL} \mathrm{~min}^{-1}\right)$. Flame ionization detection (FID) was performed at $300^{\circ} \mathrm{C}$. Injection for all the samples was $0.5 \mu \mathrm{L}$ of $1 \%$ solution of essential oil in diethyl ether, in the split mode (1:100).

\section{Gas chomatography-mass spectrometry}

GC-MS was carried out on a Hewlett-Packard 5890 gas chromatograph fitted with a fused silica SE-30 capillary column $(50 \mathrm{~m} \times 0.22 \mathrm{~mm}, 0.25 \mu \mathrm{m}$ film thickness), coupled to a HP 5971A mass selective detector. Column temperature was programmed from $70^{\circ} \mathrm{C}$ to $220^{\circ} \mathrm{C}$ at $4^{\circ} \mathrm{C} \mathrm{min}{ }^{-1}$, and helium was used carrier gas. Mass spectra were recorded in the scan mode at $70 \mathrm{eV}$.

Most constituents were tentatively identified by GC by comparison of their retention indices with those of authentic standards available in the author's laboratory or with retention indices in close agreement with references (Adams 2001; Joulain and König 1998; Swigar and Silverstein 1981). Further identification was achieved by GC/MS. The mass spectral fragmentation patterns were compared with those stored (Wiley built-in library) in the spectrometer data base.

\section{RESULTS AND DISCUSSION}

Table 1 lists the results for the chemical composition of the three species: Th. villosus subsp. lusitanicus, Th. xtoletanus, and Th. mastichina.

The majority component in the case of Th. mastichina was 1,8 -cineole $(76.1 \%)$. At far lower percentages there appeared $\beta$-myrcene $(7 \%)$, $\alpha$-terpineol $(4.1 \%)$, camphene $(3.9 \%)$, trans-dihydro- $\alpha$-terpineol $(1.7 \%)$, linalool $(1.4 \%)$, and limonene $(1.1 \%)$. This thyme is endemic to the Iberian Peninsula, and is widely distributed within that area. Three types have been described for it: the 1,8-cineole type (Morales 1986; Carvalho 1994; Faleiro et al. 1999; Miguel et al. 1999a, b, 2003), the linalool type (Gavińa et al. 1974; Miguel et al. 2003), and an intermediate type (García et al. 1984; Tomei et al. 1995). The present study population could be included in the so-called 1.8-cineole type, although the percentage that we found for this majority component (76.1\%) is among the highest recorded for this species.

For Th. villosus subsp. lusitanicus, the principal components quantitatively were linalool $(49.6 \%)$, camphor $(9.8 \%)$, cis-sabinene hydrate $(9.0 \%), \alpha$-pinene $(7.1 \%)$, camphene $(5.6 \%),(Z)-\beta$-ocimene $(4.1 \%)$, and sabinene $(2.8 \%)$. This thyme is also endemic to the Iberian Peninsula, but its range is far smaller (Estremadura and Beira Litoral in Portugal, and specific zones of Ciudad Real, and Cáceres in Spain). Its essential oil has a high degree of chemical polymorphism, with various types having been described for both the Portuguese (linalool; linalool/terpinen4-ol/trans-sabinene hydrate; linalool/1,8-cineole; geranyl acetate/geraniol; geranyl acetate/geraniol/1,8-cineole; Salgueiro et al. 2000b) and the Spanish (camphor/1,8-cineole; camphor/1,8-cineole/linalool; Pérez-Alonso and VelascoNegueruela 1984) populations. A recent study (Morales and López-González 2008) has revealed that the populations studied in the province of Toledo (Pérez-Alonso and Velasco-Negueruela 1984; Morales 1986) and having the type camphor/borneol correspond to a different taxon: Th. villosus subsp. velascoi R. Morales \& G. López.

The present study population stands out for its high linalool content $(49.6 \%)$, followed by camphor and cis-sabinene hydrate with values below $10 \%$. These results are novel because the linalool component had not previously been found to exceed $18.2 \%$ in the Spanish or $24.5 \%$ in the Portuguese populations. 
TABLE 1. The composition of the essential oils of Thymus villosus subsp. lusitanicus, Thymus xtoletanus and Thymus mastichina.

\begin{tabular}{|c|c|c|c|c|c|}
\hline Compound & RI & RTM & $\mathrm{A} \%$ & $\mathrm{~B} \%$ & $\mathrm{C} \%$ \\
\hline$\alpha$-thujene & 926 & 4,91 & 0.7 & 0.6 & - \\
\hline$\alpha$-pinene & 934 & 5.05 & 7.1 & 2.8 & 0.3 \\
\hline camphene & 949 & 5.3 & 5.6 & 2.2 & 3.9 \\
\hline sabinene & 979 & 5.65 & 2.8 & 3.2 & 0.1 \\
\hline 1-octen-3-ol & 981 & 5.7 & $\mathrm{t}$ & - & - \\
\hline$\beta$-pinene & 985 & 5.75 & 0.7 & 1.3 & 0.8 \\
\hline$\beta$-myrcene & 991 & 5.86 & 0.4 & 0.2 & 7.0 \\
\hline$\alpha$-phelandrene & 1006 & 6.19 & - & - & $\mathrm{t}$ \\
\hline$\alpha$-terpinene & 1018 & 6.39 & 0.4 & 0.5 & 0.3 \\
\hline$p$-cymene & 1020 & 6.53 & 0.3 & 1.3 & 0.5 \\
\hline limonene & 1025 & 6.62 & 0.1 & 6.9 & 1.1 \\
\hline$\beta$-phelandrene & 1025 & 6.69 & 0.2 & 14.5 & $\mathrm{t}$ \\
\hline 1,8 -cineole & 1026 & 6.69 & 0.2 & 25.5 & 76.1 \\
\hline$(Z)$ - $\beta$-ocimene & 1038 & 6.91 & 4.1 & 8.1 & 0.1 \\
\hline$(E)$ - $\beta$-ocimene & 1051 & 7 & $\mathrm{t}$ & - & $\mathrm{t}$ \\
\hline$\gamma$-terpinene & 1060 & 7.17 & 0.6 & 0.4 & 0.6 \\
\hline cis-sabinene hydrate & 1066 & 7.35 & 9.0 & 0.2 & 0.2 \\
\hline cis-linalool oxide & 1078 & 7.44 & 0.8 & 0.1 & - \\
\hline trans-linalool oxide & 1090 & 7.75 & 0.9 & - & - \\
\hline terpinolene & 1091 & 7.77 & - & $\mathrm{t}$ & $\mathrm{t}$ \\
\hline trans-sabinene hydrate & 1096 & 7.82 & - & - & $\mathrm{t}$ \\
\hline linalool & 1102 & 7.93 & 49.6 & 3.4 & 1.4 \\
\hline nonanal & 1104 & 8.01 & $\mathrm{t}$ & - & - \\
\hline 1-octen-3-yl acetate & 1110 & 8.09 & $\mathrm{t}$ & $\mathrm{t}$ & - \\
\hline$\alpha$-campholenal & 1124 & 8.32 & $\mathrm{t}$ & - & - \\
\hline cis-verbenol & 1140 & 8.89 & - & $\mathrm{t}$ & - \\
\hline camphor & 1148 & 9.01 & 9.8 & 4.5 & 0.2 \\
\hline trans-dihydro- $\alpha$-terpineol & 1165 & 9.42 & - & - & 1.7 \\
\hline borneol & 1172 & 9.44 & 1.9 & 0.2 & 0.1 \\
\hline terpinen-4-ol & 1174 & 9.67 & 0.5 & 0.9 & 0.9 \\
\hline$p$-cymen-8-ol & 1181 & 9.8 & $\mathrm{t}$ & 0.1 & - \\
\hline 1- $\alpha$-terpineol & 1188 & 9.94 & $\mathrm{t}$ & 2.7 & 4.1 \\
\hline cis-dihydrocarvone & 1205 & 10.09 & $\mathrm{t}$ & - & - \\
\hline myrtenol & 1206 & 10.1 & - & 0.7 & - \\
\hline verbenone & 1209 & 10.2 & - & 1.3 & - \\
\hline$p$-cymen-7-ol & 1286 & 11.80 & $\mathrm{t}$ & - & - \\
\hline thymol & 1290 & 12.1 & $\mathrm{t}$ & $\mathrm{t}$ & - \\
\hline carvacrol & 1298 & 12.23 & $\mathrm{t}$ & $\mathrm{t}$ & - \\
\hline thymol acetate & 1365 & 12.75 & - & - & 0.2 \\
\hline carvacrol acetate & 1372 & 13.4 & - & - & 0.1 \\
\hline geranyl acetate & 1400 & 14 & - & 0.1 & - \\
\hline$\beta$-bourbonene & 1405 & 14.23 & 0.1 & $\mathrm{t}$ & $\mathrm{t}$ \\
\hline$\beta$-elemene & 1410 & 14.32 & 0.1 & $\mathrm{t}$ & - \\
\hline$\alpha$-cedrene & 1414 & 14.43 & 0.2 & - & - \\
\hline$\alpha$-gurjunene & 1415 & 14.75 & - & $\mathrm{t}$ & - \\
\hline (E)-caryophyllene & 1423 & 14.98 & 0.7 & 1.5 & $\mathrm{t}$ \\
\hline$\beta$-gurjunene & 1443 & 15.34 & 0.1 & 0.0 & - \\
\hline$\gamma$-elemene & 1443 & 15.54 & - & - & $\mathrm{t}$ \\
\hline$\alpha$-humulene & 1458 & 15.68 & $\mathrm{t}$ & $\mathrm{t}$ & 0.1 \\
\hline allo-aromadendrene & 1463 & 15.85 & $\mathrm{t}$ & 0.1 & - \\
\hline$\gamma$-muurolene & 1465 & 16.25 & 0.2 & 1.1 & - \\
\hline$\beta$-selinene & 1480 & 16.56 & $\mathrm{t}$ & $\mathrm{t}$ & - \\
\hline$\beta$-bisabolene & 1494 & 16.7 & $\mathrm{t}$ & 0.4 & - \\
\hline$\gamma$-cadinene & 1510 & 16.87 & 0.2 & 2.8 & $\mathrm{t}$ \\
\hline d-cadinene & 1520 & 17.02 & $\mathrm{t}$ & $\mathrm{t}$ & - \\
\hline$(E)$ - $\gamma$-bisabolene & 1522 & 17.35 & - & 3.5 & - \\
\hline elemol & 1542 & 17.53 & 1.2 & $\mathrm{t}$ & 0.2 \\
\hline$(E)$-nerolidol & 1558 & 17.74 & 1.0 & 0.1 & - \\
\hline ledol & 1560 & 17.95 & 0.2 & $\mathrm{t}$ & - \\
\hline germacrene D-4-ol & 1572 & 18.13 & $\mathrm{t}$ & $\mathrm{t}$ & - \\
\hline spathulenol & 1575 & 18.16 & - & - & $\mathrm{t}$ \\
\hline caryophyllene oxide & 1578 & 18.32 & $\mathrm{t}$ & 2.4 & $\mathrm{t}$ \\
\hline viridiflorol & 1585 & 18.53 & $\mathrm{t}$ & 3.3 & 0.2 \\
\hline 1-epi-cubenol & 1610 & 18.89 & 0.1 & 0.2 & - \\
\hline$\gamma$-eudesmol & 1635 & 19.37 & 0.3 & 2.7 & - \\
\hline epi- $\alpha$-mouurolol & 1644 & 19.62 & $\mathrm{t}$ & 0.2 & - \\
\hline cubenol & 1645 & 20.08 & $\mathrm{t}$ & $\mathrm{t}$ & - \\
\hline$\beta$-eudesmol & 1649 & 20.41 & - & - & $\mathrm{t}$ \\
\hline$\alpha$-eudesmol & 1652 & 20.63 & - & - & $\mathrm{t}$ \\
\hline$\alpha$-cadinol & 1653 & 20.68 & - & - & $\mathrm{t}$ \\
\hline Yield (mL/100 g) & & & 2.0 & 2.3 & 2.9 \\
\hline
\end{tabular}

With respect to our analysis of the essential oil of Th. xtoletanus, we must outline the components 1,8-cineole $(25.5 \%), \beta$-phelandrene $(14.5 \%),(Z)$ - $\beta$-ocimene $(8.1 \%)$, and limonene $(6.9 \%)$. There are no published antecedents for the chemistry of this essential oil, so this is the first study.

Similarities between Th. xtoletanus and its parents there exist. The majority component of Th. xtoletanus was 1,8cineole $(25.5 \%)$, as it also was for Th. mastichina (76.1\%). Moreover, the significant presence in the hybrid of other components $[(Z)-\beta$-ocimene $(8.1 \%)$, camphor $(4.5 \%)$, sabinene $(3.2 \%), \alpha$-pinene $(2.8 \%)]$ was similar to those found in Th. villosus subsp. lusitanicus $[(Z)$ - $\beta$-ocimene (4.1\%), camphor $(9.8 \%)$, sabinene $(2.8 \%)$, $\alpha$-pinene $(7.1 \%)]$.

Nevertheless, there was a significant presence of some components in Th. xtoletanus which only present very low levels in its parents. These were: $\beta$-phelandrene (14.5\%), limonene $(6.9 \%),(E)-\gamma$-bisabolene $(3.5 \%)$, viridiflorol (3.3\%), $\gamma$-cadinene $(2.8 \%), \gamma$-eudesmol $(2.7 \%)$ caryophyllene oxide $(2.4 \%)$, and $\gamma$-muurolene $(1.1 \%)$.

One therefore can infer from these results that the morphologically detected hybrid character of the plant is also reflected in the chemical composition of its essential oil. The study confirms the hybrid origin of Th. xtoletanus as intermediate between Th. mastichina and Th. villosus subsp. lusitanicus.

\section{ACKNOWLEDGEMENTS}

This work was partly supported by the Instituto Nacional de Investigación y Tecnología Agraria y Alimentaria (INIA) (RF00-019-C2-2) and the Fundación para el Desarrollo de la Ciencia y la Tecnología de Extremadura (FUNDECYT) (PRI-III 3PRO5A043). Authors wish to thank the helpful collaboration of Jesús Sanz (Centro de Química Orgánica "Manuel Lora-Tamayo" C.S.I.C.) and Robert Chatwin for the translation of the original manuscript.

\section{LITERATURE CITED}

ADAMS R.P. 2001. Identification of essential oil components by gas chromatography/mass spectroscopy. Allured Publishing co., Carol Stream, IL.

BLANCO J., VÁZQUEZ F.M., RUIZ T. 2007. Revisión de los géneros Thymbra L. y Thymus L. (Lamiaceae) en Extremadura (España). Fol. Bot. Extrem., 1: 27-53.

CARVALHO J. 1994. Qualidade fragrante e potencialidades de arbustivas espontáneas das Serras de Aire e Candeeiros. Silva Lusitanica., 2: 193-206.

Council of Europe 1996. European Pharmacopoeia 3rd. Strasbourg.

FALEIRO L., MIGUEL G.M., GUERRERO C.A.C., BRITO J.M.C. 1999. Antimicrobial activity of essential oils of Rosmarinus officinalis L., Thymus mastichina (L.) L. ssp. mastichina and Thymus albicans Hoffmanns \& Link. Acta Hort., 501: 45-48.

GARCÍA M.C., GARCÍA D., MUÑOZ F. 1984. Avance de un estudio sobre las esencias de Thymus mastichina L. español (majorana de España). An. INIA /Ser. Forestal/ N., 8: 201-218 .

\footnotetext{
RI - retention index according to n-paraffins on DB-1 column; RTM retention time in GLC-MS; $\mathrm{t}-$ trace $(<0.1 \%)$.

A - Thymus villosus subsp. lusitanicus; $\mathbf{B}$ - Thymus xtoletanus; $\mathbf{C}-$ Thymus mastichina.
} 
GAVIÑA-MÚGICA M., TORMES-OCHOA J. 1974. Aceites esenciales de la Provincia de Guadalajara. Aceite esencial de Thymus mastichina L. Contribución al estudio de los aceites esenciales españoles. INIA. Spain, pp. 361-377.

ISTA (International Seed Testing Association). 1999. International rules for seed testing. Seed Sci. and Tech. 27, Supplement. Switzerland.

JOULAIN D., KÖNIG A.W. 1998. The Atlas of Spectral Data of Sesquiterpene Hydrocarbons. E.B.-Verlag Hamburg, Germany.

LADERO M. 1970. Nuevos taxones para la flora de Extremadura (España). Anales Inst. A. J. Cavanillas., 27: 85-104.

MIGUEL G., GUERRERO C., RODRIGUES H., BRITO J., VENÂNCIO F., TAVARES R., MARTINS A., DUARTE F. 1999a. Study of the substrate and fertilization effects on the production of essential oils by Thymus mastichina (L.) L. ssp. mastichina cultivated in pots. (D. Anaç \& P. Martin-Prével eds) Improved Crop. Quality by Nutrient Management. Holland., 46: 201-204.

MIGUEL M.G., GUERRERO C.A.C., BRITO J.M.C., VENÂNCIO F., TAVARES R., MARTINS A., DUARTE F. 1999b. Essential oils from Thymus mastichina (L.) L. ssp. mastichina and Thymus albicans Hoffmanns. \& Link. Acta Hort., 500: 59-63.

MIGUEL M.G., FIGUEIREDO A.C., COSTA M.M., MARTINS D., DUARTE J., BARROSO J.G., PEDRO L. 2003. Effect of essential volatile oil isolated from Thymus albicans, Th. mastichina, Th. carnosus and Thymbra capitata in sunflower oil. Nahrung., 47: 397-402.

MORALES R. 1986. Estudio químico de aceites esenciales. In: R. Morales. Taxonomía del género Thymus L. excluida la Sect. Serpyllum (Miller) Benthem en la Península Ibérica. Ruizia. Spain, pp. 71-91.

MORALES R. 1995. Híbridos de Thymus L. (Labiatae) en la Península Ibérica. Anales Jard. Bot. Madrid., 53: 199-211.

MORALES R., LÓPEZ-GONZÁLEZ G. 2008. Thymus villosus subsp. velascoi (Labiatae), nueva subespecie para la Península Ibérica. Bot. Complut., 32: 185-191.
PÉREZ-ALONSO M.J., VELASCO-NEGUERUELA A. 1984. Essential oil analysis of Thymus villosus subsp. lusitanicus. Phytochemistry., 23: 581-582.

SÁEZ F. 1995. Essential oil variability of Thymus zygis growing wild in southeastern Spain. Phytochemistry., 40: 819-825.

SALGUEIRO L.R., PROENÇA DA CUNHA A.P., PAIVA J. 1993. Chemotaxonomic characterization of a Thymus hybrid from Portugal. Flavour Fragr. J.., 8: 325-330.

SALGUEIRO L.R., VILA R., TOMAS X., CAÑIGUERAL S., PAIVA J., PROENÇA DA CUNHA A., ADZET T. 2000a. Essential oil composition and variability of Thymus lotocephals and Thymus xmourae. Biochem. Syst. Ecol., 28: 457-470 .

SALGUEIRO, L.R., VILA R., TOMÀS X., CAÑIGUERAL S. PAIVA J, PROENÇA DA CUNHA A., ADZET T. 2000b. Chemotaxonomic study on Thymus villosus from Portugal. Biochem. Syst. Ecol., 28: 471-482.

SÁNCHEZ P., LÓPEZ J.A., SÁNCHEZ F.J., MORALES R. 2004. Thymus xfaustinoi, híbrido nuevo del sureste de la Península Ibérica. Anales de Biología. 26: 175-178.

SORIANO M.C., SOTOMAYOR J.A., CORREAL E., SÁNCHEZ-GÓMEZ P., GARCÍA-VALLEJO C.G. 1997. Chemical composition of the essential oil of Thymus xarundanus Wilk., and its parents T. mastichina L. and T. baeticus Boiss ex Lacaita. J. Essent. Oil Res., 9: 593-594.

SWIGAR A.A., SILVERSTEIN R.M. 1981. Monoterpenes. Aldrich, Milwaukee, WI.

TOMEI T.E., CIONI P.L., FLAMINI G., STEFANI. A. 1995. Evaluation of the chemical composition of the essential oil of some Lamiaceae from Serranía de Ronda (Andalucía, Spain). J. Essent. Oil Res., 7: 279-282.

TZAKOU O., CONSTANTINIDIS T. 2005. Chemotaxonomic significance of volatile compounds in Thymus samius and its related species Thymus atticus and Thymus parnassicus. Biochem. Syst. Ecol., 33: 1131-1140. 